\title{
Civilization and sexual abuse: selected Indian captivity narratives and the Native American boarding-school experience
}

\begin{abstract}
This paper offers a contrastive analysis of Indian captivity narratives and the Native American boarding-school experience. Indian captivity narratives describe the ordeals of white women and men, kidnapped by Indians, who were separated from their families and subsequently lived months or even years with Indian tribes. The Native American boarding-school experience, which began in the late nineteenth century, took thousands of Indian children from their parents for the purpose of "assimilation to civilization" to be facilitated through governmental schools, thereby creating a captivity of a different sort. Through an examination of these two different types of narratives, this paper reveals the themes of ethnocentrism and sexual abuse, drawing a contrast that erodes the Euro-American discourse of civilization that informs captivity narratives and the boarding-school, assimilationist experiment.
\end{abstract}

Keywords: Native Americans, captivity narratives, boarding schools, sexual abuse, assimilation.

\section{Introduction}

Comparing Indian captivity narratives and writings on the Native American board- ingschool experience is as harrowing as it is instructive. Indian captivity narratives, mostly dating from 1528 to 1836 , detail the ordeals of white, Euro-American women and men kidnapped by Native peoples. Separated from their families and white "civili- zation," they subsequently lived for a time among Indian tribes. Such narratives can be seen as a prelude to a sharp reversal that occurred in the late nineteenth century under

U.S. President Ulysses S. Grant's “peace policy" of Native assimilation through white education. Similar to the experiences chronicled in captivity narratives, the Native

1 Address for correspondence: Institute of English, University of Opole, pl. Kopernika 11a, 45-040 Opole, Poland. E-mail: ewa.iwona.skal@gmail.com 
American boarding-school experience separated Indians, in this particular instance - children and adolescents, from their families and communities. Thousands, at the behest of the U.S. government, were taken from their parents for instruction in white boarding schools - a captivity of a different sort, meant to transform the children through contact with "civilization." The boarding-school literature that emerged from the Native American boarding-school experience offers detailed accounts by Native American children, whereas Indian captivity narratives describe the experiences of EuroAmerican captives. The former focus on children who were forced to conform to ways of life favored by the "white man" and to endure extremely difficult living condi- tions, and often, repeated sexual abuse. Such literature poses a fundamental contrast Indian captivity narratives and the experience of white victims. Through exami- nation of these two different types of narratives, this paper reveals the underlying themes of ethnocentrism and sexual abuse - drawing a contrast that erodes the Euro- American discourse of civilization underlying captivity narratives and the boarding- school, assimilationist experiment.

\section{Indian Captivity Narratives}

The beginning of Captivity Narratives is often related to a woman by the name of Mary Rowlandson after she published her narrative work in 1862, describing her captivity by one Indian tribe. This publication created a fixed structure for every text of this genre. The main themes visible throughout the text generally focus around the feeling of helplessness of the captives, the mental struggles during their captivity, and are accompanied by the terrifying description of the captors and their behaviour (Showalter 2013: n.p.). As far as Indian captivities are concerned, the negative descriptions of the captors include "stereotypes of savagery, civilization, and feminine purity that animate the dramatic action," and are held up in contrast to descriptions of a superior white civilization (Johnson 2016: n.p.). They also often present readers with graphic violence, exemplified in the murder and torture of the captives. Having said this, however, some examples of Indian captivities, even that of Rowlandson's, just as often depict Indians being civil toward their victims. In some cases, captives assimilate and do not wish to return to "civilization." In 1853, Samuel Gardner Drake published Life in the Wigwam, the first collection of narratives of white women and men describing conditions under Indian captivity during the Anglo-Indian and American-Indian wars. Some captives were held for months or even years. Some escaped or were sold by the Indians back to the whites; while remained with the Indians until their deaths.

Life in the Wigwam's first narrative is that of John Oritz, presented by those who knew him well (the author is not known). Oritz was captured by the Apalachee tribe in 1528, in the aftermath of the Spanish expedition under Pánfilo de Narváez, whose members considered Natives little more than savages. The Apalachee were Southeast Indians 
who lived in present-day Florida (Waldman 2006: 21). Angry that the Spanish wanted to cross their lands in search of treasure, the Apalachee attacked the expedition. When they did not return, a party was sent to search for them that included John Oritz, who was quickly captured. Initially, the Apalachee want to kill Oritz. However, their chief's daughter stands up in his favor, and they change their minds. Oritz has the opportunity to inspect the Apalachee temples, in which he describes seeing human remains and body parts being eaten by animals. Oritz experiences what to him is a nightmare in which he has to persevere among beasts who threaten to kill him if he does not obey. Oritz escapes to a different Apalachee village, where the atmosphere is much improved. No Native from this village causes him discomfort, and their culture, language and spiritual practices start to fascinate him. Oritz, after some time, has no desire to return to his own people, wanting to stay with the Apalachee. His appearance changes and he begins to look and speak like the Apalachee. Along with his adoptive tribe, Oritz is ultimately captured by Spanish men and dies of unknown causes in 1548 (Drake 1853: 4, 14-20). Remarkably, this early narrative provides an example of a captive who wanted to stay with the Apalachee due to their kindness and respectfulness. This amounts to a reversal of what later became a cemented, standard view of Indian savagery vs. white civilisation. Oritz, in becoming accustomed to life with the Apalachee, suggests that they were not savages at all, but members of a civilisation that lived harmoniously and peacefully.

Mary Rowlandson authored what has remained the most famous captivity narrative, "Narrative of the Captivity and Restoration of Mrs. Mary Rowlandson," in 1682. It is said to have initiated the captivity narrative genre, influencing future works of this sort (Skarborough 2011:121; "Mary Rowlandson"). Rowlandson was captured during King Phillip's War, which began in 1675. At this time, English, Puritan settlers began to raid the Wampanoag lands in the Northeast, wanting to control them. It is also important to note that the Puritans believed that they had the right to control the lands in which, according to their own interpretation, Natives were satanic creatures. They consolidated this belief by saying that the Natives' dances (powwows) were, indeed, a celebration of Satan (Tetek 2010:31). Puritan encroachment upon the Wampanoags provoked the burning of settlers' houses, the murdering of several people, and kidnapping. The Wampanoags' Narragansett allies abducted Rowlandson in present-day Rhode Island (Waldman 2006:183). After they burned her house down and killed members of her family, she was taken captive along with her youngest daughter.

In her narrative, the exact terms Rowlandson uses to describe the Indians are "savages, heathens, beasts" (1853: 22). The savageness of the Narragansett manifests itself, in her telling, especially at times when they start chanting. She is terrified and disgusted by their appearance, dances, and everything connected with their culture: "Oh the roaring, and singing, and dancing, and yelling of those black creatures in the night, which made the place a lively resemblance of hell," she remarks. The Narragansett are, in her view, 
sub-human and inferior, all that conflicts with European culture and white "civilisation" (1853: 55). Rowlandson, a Puritan, believes that God will rescue her. Christianity was one of the prominent ideals of white "civilisation," which Rowlandson returns to throughout her narrative, whereas the Narragansett spiritual practices amount to Satanism. Rowlandson is later ransomed by and reunited with her husband. Yet curiously, when the narrative concludes it is clear that the Indians have not harmed Rowlandson in any way, and instead have mostly been helpful and civil toward her (Rowlandson 1853:55-60).

Quintin Stockwell was captured around the same time as Rowlandson, in 1677 . He was abducted by the Pocomtuc during the part of King Phillip's War that occurred in present-day Connecticut. In much of the colonial period, the Pocomtuc were initially very civil with the white settlers, engaging in trade. However, these civil relations became strained as the settlers wanted to claim more land as their own. The Pocomtuc, enraged at this turn of events, allied with other Native American tribes to fight the English (Bruchac 2011: 32). Stockwell's narrative was published in 1684. The narrator describes Indian behaviour as barbaric because the captives are "staked down," i.e. their arms and legs were tied and stretched out so that they could not move or escape (1853: 64). Initially, he is beaten by them and given very small amounts of food. Once, when Stockwell is cold, and cannot carry wood or perform duties for the Indians, the captors are very cruel to him, beating him and threatening to kill him. However, there are also instances of kindness. When Stockwell is very hungry, one of the Pocomtuc hides a piece of meat and gives it to him, so that he is fully fed. What is more, when Stockwell is too weak and exhausted to make the journey and walk on his own, he is carried by one of the Indians who stays behind to help him, saving his life in the process. Eventually, Stockwell ends up with the French, who buy him from the Indians. Not long after, he returns to New England. Although initially, he was treated cruelly by the Indians, whom he thought to be merely savage and sub-human because of their animal skins, temperament, and nutritional habits, later one observes that he was cared for and offered compassion while in captivity (Stockwell 1853: 65).

Elizabeth Hanson's narrative was published in 1821. She was captured by the Abenaki in 1724, along with her four children and maid in present-day Maine (Calloway 2015: 1). It is important to note that both the English and French were imperial rivals at the time, which resulted in tense relations. In 1601, the Abenaki's had developed amicable relations with the French. The two allied against the English. The English posed a great threat to the Abenaki lands, culture and healthy well-being. European diseases spread throughout Native American lands, and many died as a consequence. The Abenakis fought in King Phillip's War, and in 1722, the Dummer War began between the Abenaki and the English, which lasted until 1727. During this period, Elizabeth Hanson was captured. In her narrative, at the outset she is very frightened of the Abenakis, their spiritual practices, and eating habits. They are sometimes very cruel to her, including 
a time when the chief of the tribe strikes her and her son, which, in her telling, highlights their savage disposition. She finds great comfort in quoting the Bible and prays frequently for herself and her children to survive. Here, once again, Christianity is mentioned as a strong contrast between civilisation and, in the settlers' view, the savage Natives. Having become very weak to the point of not being able to give breast milk to her youngest child, a kind Abenaki woman tells her what to feed her baby. This act reveals an example of behavior by these Native Americans who live in organised societies, and aid each other in times of need. Moreover, one of the Abenaki offers to carry her child for her, which surprises Hanson greatly. After their last move, she is sold to the French and reunited with her husband and children. It is crucial to note that many Abenakis are very generous towards Hanson. She is never abused in any way, posing a contrast to the settlers view of the Indians as savage (Hanson 1853:121).

Isabella M'Coy was captured in present-day Epsom, New Hampshire in 1747. Her narrative, entitled "Narrative of the Captivity of Isabella M'Coy" is told by her friends, whose names are unknown. She was captured by the Western Abenaki tribe during King George's War, which began in 1744 and ended in 1748, when the Abenaki's had once again joined forces with the French to fight the English (Calloway 2015:2). Initially, separated from her husband and son, she thinks of escaping but rejects the idea knowing that she might be killed. Thinking that the Abenaki will torture and kill her, her initial belief is that they are monsters who will want to harm her. However, although she believes that she will suffer with them, she is treated well and cared for. They provide her with food every day, and do everything to make her feel comfortable. Surprisingly, she sheds her prejudices and comes to the conclusion that Indians are good and generous. Once in Canada, M'Coy is sold to the French, but wishes to remain with her Indian captors (Drake 1853:145-147).

The above narratives, though diverse, offer a cross-section of the genre in which white captives often overcome preconceptions after receiving kind treatment from Indian tribes. The following section looks at white-Indian relations from a different perspective, briefly discussing the subjugation of Native Americans in the project of American expansionism, the reservation system, as well as the historical background behind the boarding-school assimilationist experiment.

\section{Native Americans and assimilationist boarding schools}

The settler-colonial project that resulted in the Indian-American wars contributed to a massive decline in Indian communities from the 1800s, and a large reservation system that kept Natives segregated from white society and under the control of the Office of Indian Affairs (OIA). Much of white society perceived Natives negatively. As Andrea Smith notes in Conquest: Sexual Violence and American Indian Genocide, they were seen as "the dirtiest lot of human beings on earth" (2015a: 9-10). President Grant's peace 
policy, which was put into practice in 1869 , sought to stem the violence of the past and promote assimilation. Schools on Indian reservations were run by representatives of church groups, who taught Indian children how to read and write in English (Smith 2015a: 35). Then in 1882, the Indian Rights Association was established with the key goal of securing the assimilation of Indians into American society. They believed that the reservation system kept Natives accustomed to their culture and religious beliefs, which contributed to "backwardness.". Carl Schurtz, the then secretary of the Interior, stated that the only solution for the Natives, if they resisted assimilation, was death: "Indians were confronted with this stern alternative: extermination or civilization"(qtd. in Adams 1999: 15). A later Commissioner of Indian Affairs, Henry Price, stated much the same sentiments: "Savage and civilised life cannot live and prosper on the same ground. One of the two must die" (qtd. in Adams 1999: 15).

Army officer Richard Pratt became the key figure in the process of assimilating Native Americans, by founding the first Indian off-reservation boarding school in Carlisle, Pennsylvania, having beforehand undertaken a process of "civilising" imprisoned Indians at Fort Marion, Florida (Adams 1999: 40; Peterson 2012: 3). Carlisle was located far away from the reservations, which meant that Indian children were unable to see their families while there. Pratt stated that "The only alternative left [for the Indians] is civilization or annihilation, absorption or extermination" (qtd. in Adams 1995: 16). The Carlisle Industrial School in Pennsylvania was opened on November 1, 1979. Pratt recruited children from the Rosebud and the Pine Ridge agencies in the Dakotas for the school. The aspects predominantly highlighted by Pratt in order to "civilise" the Native children were: English reading and writing instruction, conversion to Christianity, restricted or forbidden contact with their families, and strict school regulations (Smith 2015a: 36; Adams 1999: 52). Amelia Katanski claims that the structure of the boarding school was "culturally genocidal"; she stated that "Carlisle was (...) designed to destroy tribal nations and strip Native children of their cultures, languages, and religions" (2005: 2).In his autobiography, Pratt stated that the goal of Carlisle was "complete civilization of the Indian and his absorption into our national life"; hence, in his telling, the goal of the school was to do everything for an "Indian to lose his identity as such, to give up his tribal relations and to be made to feel that he is an American citizen" (qtd. in Katanski 2005: 4).

Boarding-schools established across the United States under Pratt's blueprint were very strict and the forms of punishment they employed were often harsh. If pupils disobeyed the authorities, they were often beaten. At many schools, children also suffered from illnesses due to unsanitary conditions and lack of immunity to European diseases (EchoHawk 2000: 85). Yet the reformer's defining goal, was, as stated by Pratt, to "kill the Indian and save the man inside them" (qtd. in Smith 2003: 36, 115). Alongside Carlisle, twenty-five other boarding schools were opened for Indians in the United States. Pratt 
wanted them to be opened, so as to expose their students to American life, away from their own surroundings. Among them were "Chemawa School" in Oklahoma, opened a year after Carlisle, in 1880. In 1890, "Fort Mojave" was opened in Arizona. Four new schools were opened in 1983: "Fladreau" in South Dakota, "Pipestone" in Minnesota, "Mount Pleasant" in Michigan, and "Tomah School" in Wisconsin. In 1898, three new schools started recruiting in South Dakota, the "Chamberlain School," "The Morris School" in Minnesota, as well as "Rapid City" in South Dakota (qtd. in Adams 1999: 57-58). It is also important to note the average attendance statistics in boarding schools and off-reservation schools; in 1877 the total attendance for both schools totalled 3,598, whereas in 1900 it totalled 21,568. Interestingly, at some schools, conditions were substantially different from others. At a school in Albuquerque, parents were permitted to visit their children quite frequently (qtd. in Adams 1999: 57-58). However, some schools became notorious for employing teachers that were reported to have abused students, sexually or physically.

In the twentieth century, Indian boarding schools continued to be opened, and the abuse also continued. For instance, the Wrangell Institute was opened in 1932 and is said to have had instances of abuse (Hirshberg \& Sharp 2005:11-13). At the Tekakwitha Orphanage, opened in 1940 in South Dakota, Natives also experienced frequent abuse from teachers. The school was run by Father John Pohlen and functioned until 1970, In 2010, the entire building was taken down (Packtor 2013: n.p.). What is more, Smith claims that at the "Hopi Day School", one teacher repeatedly abused students without consequence. In her findings, similar incidents are said to have occurred at a North Carolina government school, where a teacher was reported to have abused children during his employment from 1971 to 1985 , as well as at the Kaibito school (Smith 2015a: 36; Smith 2015b: 6;).

After the implementation of the Indian Reorganization Act in 1934, boarding schools became less strict in terms of assimilation, but they still propagated "white values" and encouraged conversion to Christianity. Some of the schools operated strictly on the ideals of the Catholic Church, which were run by priests. Here, Native students were taught by nuns: "It was the religious orders (...) that were responsible for operating the Native American schools" (Anderson 2019: n.p.). At such institutions, Native children were frequently encouraged to pray and exemplify Christian behaviour (Smith 2015a: 37). Interesting to note is the fact that some schools went by the name of orphanages, but did not really recruit orphans. Instead, they recruited children whose parents were in a poor financial position. Some students had even been taken from their families for unspecific reasons. The latter believed that the schools would care for the children. However, the reality was sometimes very different (Woodard 2011: n.p.). The most striking thing to note is the sexual abuse that students experienced at some boarding schools, even late 
into the twentieth century (Anderson 2019: n.p.). The following section will give accounts of abuses experienced by former students of selected boarding schools, namely the accounts of Howard Wanna and Mary Catherine Renville, as well as Severyn Zephier.

\section{The Native American boarding school experience and sexual abuse}

Autobiographical Indian boarding-school narratives detail the "captivity" ordeals of Indian children who were forced to assimilate to white ways under the policies of the United States government, and in some cases were also sexually abused. Smith states: "Despite the epidemic of sexual abuse in boarding schools, the BIA [The Bureau of Indian Affairs] did not issue a policy on reporting sexual abuse until 1987 and did not issue a policy to strengthen the background checks of potential teachers until 1989" (2015a: 38). Stephanie Woodard, an American investigative journalist and a long-time member of the Native American Journalists Association, interviewed Native Americans about sexual abuse at the schools they attended (Woodard 2011: n.p.; "Stephanie Woodard"). Native American children, years after their assimilation into white "civilization," have now opened up about their difficult experiences.

At the Hopi School in Arizona, it is reported that students experienced frequent sexual abuse from one of the teachers. Even today, the matter has not been thoroughly investigated, which, as Smith claims, is a violation of human rights (2015a: 38). Smith has even reported on how some Native children were involuntarily sterilized; in one case, children of girls impregnated by the school's representatives, had been murdered (2015a: 42). At Wrangell Institute, a school for Alaska Natives, Hirshberg and Sharp have reported on and spoken to the victims, who have confessed to being abused by teachers at the school in 1935 (2005:11-13).

One former Lakota student, Howard Wanna, who died in 2011, at the age of 60, recounts being abused by the teachers who were supposed to take care of the children at the Tekakwitha school. Wanna had been mistreated from the age of four. He claims that this happened to many other boys at Tekakwitha as well. Apart from the detailed disturbing abuse he describes, he also mentions that at bath time all the boys were scrubbed so hard that their backs were bruised when they got done bathing. This experience left a painful psychological mark on him, and because of it, he was unable to live a normal life. Here are his own questioning words:

I often wonder how so many paedophiles ended up at Native American schools. Father Pohlen wasnot onlya pervert; healsohired theworst of theworst, which meant none of the Tekakwitha staff would protect us from the others. How did he find them? Is there someone in the Church 
you cancall to request problem priests and nuns? Was there a dual plan to hurt Native Americans while taking care of the paedophiles? Was this genocide? It's so confusing, but it's also just plain evil. (qtd. in Woodard 2011: n.p.)

Another Lakota victim, Mary Catherine Renville, recalls her assimilation at the Tekakwitha School:

All I remember of my earliest years at Tekakwitha was being hungry and a punishment that consisted of being placed in a dark crawl space. When I was 6 , they moved me from the Papoose House for babies to the main building so I could start school. The nuns there would take us to their private quarters and do things to our bodies that even at that young age I knew were not right. (qtd. in Woodard 2011: n.p.)

Another Lakota, Severyn Zephier, was 54 years of age when he revealed his boarding-school experiences. He suffered sexual abuse at the St. Paul's Mission School in South Dakota.

Zephier's story is unfortunately typical. He recounts that St. Paul's was terrifying for him and other students. He was beaten with a strap whenever he spoke his Native tongue, and was frequently humiliated by the teachers. The students were regularly beaten in the afternoon. He said that he was extremely scared of the nuns who were supposed to have been protecting them. On the contrary, they were, as he claims "vicious" individuals who had no mercy on them. During bed-time, the nuns used to stand in the dark room so as to frighten them. However, the most disturbing part for him and his classmates was the sexual abuse: "The child-molesters would come and go, as the Church rotated them among the Indian missions. We children stood by each other as best we could, but for a child, it was a disturbing, sickening place to be. I have often wondered where did the nuns and priests learn those things?" (qtd. in Woodard 2011: n.p.). This account adds to the weighty claims that the St. Paul's Mission School also had many instances of sexual abuse. But what is more, according to accounts, the teachers did not care about the students' well-being and treated them practically as sub-humans. Such stories present a remarkable contrast to the Indian captivity narratives detailed earlier in this paper.

\section{Conclusion}

Both the boarding-school Indian experience and Indian captivity narratives deal with the experiences of captives. The boarding-school experience presents one with accounts of those who, at the time of assimilation, were merely children, whereas Indian captivity narratives describe the life of adults forcibly taken from their families. Many boarding-schools deliberately underfed and abused children, failing to care for their physical 
and mental well-being. They believed that Native Americans needed to be "changed" in order to survive, i.e. learn how to speak the English language, as well as learn the norms of European life, which include "Victorian" clothing (consisting of uniforms in boarding schools for boys, and dresses for girls) food, table manners, agricultural skills, and the Christian faith, in order to fit into a "civilised" society. Indians as well as their culture were considered by Americans to be savage, immoral, and uncivilised. Whites generally did not accept Native American languages, rituals, hunting and spiritual practices as civilized. On the contrary, there was widespread belief that all of these customs were savage, inhuman, devilish (their dances were considered by both the British and Americans to be satanic).

One of the most potent results of such attitudes was the treatment of many boarding school pupils described in this paper. The sexual abuse pupils suffered from the hands of the schools' staff caused great pain and humiliation, leading to depression and conditions that might have been related to post-traumatic stress disorders among many Native American communities. Some children committed suicide afterwards. Some even took their lives at school (Barker 2013: 47).

The experience was often much different with white captives. When considering the analysed captivity narratives, both John Oritz and Isabella M'Coy exemplify the willingness of Europeans to stay with an Indian tribe of their own free will (Drake 1853: 17). The assimilationist experiment of Indians into white "civilisation" and the attempt of Americans to "civilize" Native American children, was supported by the willingness to "brain-wash" them and make them become distant towards their own culture, families and ways of life. In captivity narratives, on the other hand, Natives often expressed kindness and civility towards their captives. These facts present a contrast between the white discourse of the boarding-school experience underlying the assimilation of Native Americans into white "civilization," and selected Indian captivity narratives. This contrast, one could argue, undercuts the very notions of "civilization" that EuroAmericans attempted to thrust upon Native peoples.

\section{References}

Adams, W. D. 1995. Education for Extinction: American Indians and the Boarding School Experience. Lawrence: University of Kansas Press.

Anderson, P. 2019. Native American victims of sex abuse at Catholic boarding schools fight for justice. https://eu.argusleader.com/story/news/2019/05/16/native-american-sexabuse-victims-catholic-boarding-schools-south-dakota/1158590001/ (15 November 2019).

Barker, T. R. 2013. The Psychological Impact of Historical Trauma on the Native American People. Unpublished MA thesis. Regis University. 
Bruchac, M. M. 2011. Revisiting Pocomtuc history in Deerfield: George Sheldon's Vanishing Indian Act. Historical Journal of Massachusetts 39 (1-2): 30-77.

Bruchac, M. M. 2002. Wobanakiak = Abenaki Indians: linguistic notes and ethnographic terms for Abenakis. In: G. Sharrow (ed.), The Abenaki of Vermont: A Living Culture, 5-7. Vermont: Vermont Folklife Center.

Bureau of Indian Affairs. https://www.u-s-history.com/pages/h3577.html (29 May 2019).

Calloway, C. G. 2015. Abenaki. In: A. Gallay (ed.), Colonial Wars of North America, 15121763 (Routledge Revivals): An Encyclopedia, 1-2. New York: Routledge.

Cozzens, P. 2016. The Earth is Weeping: The Epic Story of the Indian Wars for the American West. London: Atlantic Books.

Davis, P. E. 2009. The Scalping of the Great Sioux Nation: A Review of My Life on the Rosebud and Pine Ridge Reservations. NY: Government Institutes.

Drake, S. G. (ed.). 1853. Life in the Wigwam. Buffalo: Derby, Orton an Mulligan.

EchoHawk, L. 2011. Child sexual abuse in Indian country: Is the guardian keeping in mind the seventh generation? New York University Journal of Legislation and Public Policy $14: 83-127$.

Fixico, D. L. 2018. When Native Americans were slaughtered in the name of 'civilization'. history. https://www.history.com/news/native-americans-genocide-united-states (27 May 2019).

Hamby, Z. 2017. King Phillip's war and Hannah Duston. Creative English Teacher website. https://cdn.shopify.com/s/files/1/2084/0507/files/King_Philip_War.pdf (18 April 2019).

Hanson, E. 1853. God's mercy surmounting man's cruelty. In: S. G. Drake (ed.), Life in the Wigwam, 113-127. Buffalo: Derby, Orton an Mulligan.

Harjo, S. S. 2004. A native child left behind. Indian Country Today website. http://www . senaa.org/DOI/achildleftbehind.htm(27 May 2019).

Hirshberg, D. \& Sharp, S. 2005. Thirty Years Later: The Long-Term Effect of Boarding-Schools on Alaska Natives and Their Communities. Anchorage: Institute of Social and Economic Research of University of Alaska.

Homstad, D. W. 2001. Abraham Lincoln: Deciding the fate of 300 Indians convicted of war crimes in Minnesota's Great Sioux uprising. Historynet.com. https://www.historynet.com/abraham-lincoln-deciding-the-fate-of-300-indians-convicted-of-warcrimes-in-minnesotas-great-sioux-uprising.htm(13 May 2019)

Hoover, H. T. 1989. The Sioux Agreement of 1889 and its aftermath. South Dakota History 19 (1): 56-94.

Jackson, C. E. \& Galli, M. J. 1977. A History of the Bureau of Indian Affairs and its Activities among Indians. University of Michigan: R \& E Research Associates.

Johnson, K. 2016. Captivity narratives. oxfordbibliographies.com. https://www.oxfordbibliographies. com/view/document/obo-9780199827251/obo-9780199827251-0115.xml 
Krupat, A. 2018. Changed Forever Volume I: American Indian Boarding School Literature. NY: SUNY Press.

Laundry, A. 2016. Abraham Lincoln: Enigmatic president, and full of contradictions. indiancountrytoday.n.pag. https://newsmaven.io/indiancountrytoday/archive/abrahamlincoln-enigmatic-president-and-full-of-contradictions-YujERMz8AkOl_Etug3JfIw/ (15 May 2019).

Lobo, S., Talbot. S. \& Morris, T. L. 2016. Native American Voices: A Reader. NY: Routledge. Mason, W. Dale. 2009. The indigenous policy of Abraham Lincoln. Indigenous Policy Journal 20.3: 1-41.

Peterson, R. 2012.The Impact of historical boarding schools on Native American families and parenting roles. minds.wisconsin.edu. https://minds.wisconsin.edu/bitstream/handle/1793/66821/Peterson.pdf? sequence=8\&isAllowed=y (19 Jan 2019).

Reservations. nativepartnership.org. nativepartnership.org.n.pag. http://www. nativepartnership.org/site/PageServer?pagename=pwna_native_reservations (4 June 2019).

Rowlandson, M. 1853. Narrative of the captivity and restoration of Mrs. Mary Rowlandson. In: S. G. Drake (ed.), Life in the Wigwam, 20-60. Buffalo: Derby, Orton an Mulligan.

Sand Creek Massacre. history.com. https://www.history.com/this-day-in-history/sandcreek-massacre (27 May 2019).

Sandefur, G. D. 1988. American Indian reservations: The first underclass areas? University of Wisconsin. https://www.irp.wisc.edu/publications/focus/pdfs/foc121f. pdf (29 May 2019).

Mary Rowlandson: American Colonial Author. britannica.com. https://www. britannica . com/biography/Mary-Rowlandson(29 May 2019).

Over 90 years serving Lakota children. https://www.stjo.org/about/history/ (12 November 2019).

Packtor, J. 2003. 4 of the worst orphanages in recent history. Borgen Magazine. https:// w w w.borgenmagazine.com/4-worst-orphanages-recent-history/\#prettyPhoto (12 November 2019).

Showalter, E. 2013. Dark places. The New YorkTimes. https : / /www. nytimes .com/2013/06/09/ books/review/tradition-of-captivity-narratives.html

Skarborough, E. 2011. Mary Rowlandson: The captive voice. The Undergraduate Review 7.23: $121-125$.

Smith, A. 2003. Not an Indian tradition: The sexual colonization of native peoples. muse. jhu.edu. https://muse.jhu.edu/article/44199/pdf (29 May 2-019)

Smith, A. 2015a.Conquest: Sexual Violence and American Indian Genocide. Duke: DUP. 
Smith, A. 2015b. Indigenous peoples and boarding schools: A comparative study. https:// www.un.org/esa/socdev/unpfii/documents/IPS_Boarding_Schools.pdf (14 November 2019).

Stephanie Woodard. The Times. inthesetimes.com. https://inthesetimes.com/community/profile/322051(13 May 2019).

Stockwell, Q. 1853. Narrative of the captivity of Quintin Stockwell, who was taken at Deerfield, in Massachusetts, by a party of inland Indians, in the year 1677. In: S. G. Drake (ed.), Life in the Wigwam, 60-70. Buffalo: Derby, Orton an Mulligan.

Taylor, T. W. 1984. The Bureau of Indian Affairs. Michigan: Westview Press.

Tetek, R. 2010. Relations between English Settlers and Indians in 17th Century New England. Unpublished MA thesis. Masaryk University. Accessed 13 May 2019. https://is.muni. cz/th/179860/pedf_m/Relations_between_English_Settlers_and_Indians_in_17th_ Century_New_England.pdf (29 May 2019).

The Trail of Tears. history.com: The History Channel Website. https : / www. history.com/ topics/native-american-history/trail-of-tears (27 May 2019).

The Treaties of Fort Loramie, 1851 and 1868. North Dakota Studies — State Historical Society of North Dakota. www.ndstudies.gov: https://www.ndstudies.gov/welcomenorth-dakota-studies (28 May 2019).

Waldman, C. 2006. Encyclopedia of Native American Tribes. NY: Checkmark Books.

Woodard, S. 2011. South Dakota boarding school survivors detail sexual abuse. newsmaven.io/indiancountrytoday/. https://newsmaven.io/indiancountrytoday/archive/ south-dakota-boarding-school-survivors-detail-sexual-abuse-QtChBLOde0-apnPNqWd3qw/ (22 Dec. 2018).

Wounded Knee. history.com: The History Channel Website. https: //www.history.com/ topics/native-american-history/wounded-knee (27 May 2019).

\section{$* * *$}

Ewa Skal is a PhD student at the Institute of English, Opole University, Poland. Her current research interests include Native American Literature as well as British and American Culture. She received an MA in English Philology (Literary Studies) in 2018, and a BA in English Philology (Business English) in 2016. Her other academic interests include feminist literature and psychological novels. 